\title{
СТАНОВЛЕННЯ НАЦІОНАЛЬНОЇ ІДЕНТИЧНОСТІ ТА ВИХОВАННЯ НАЦІОНАЛЬНО-СВІДОМОЇ ОСОБИСТОСТІ У ЗАХІДНІЙ УКРАЇНІ КІНЦЯ ХVІІІ СТ. - 1939 Р.
}

Pennsylvania [Electronic resource]. Mode od access: http://www.med.upenn.edu/. - Title from the screen.

8. Ruiz, J. G., Mintzer, M. J. \& Leipzig, R. M. (2006). The impact of E-learning in medical education [Electronic resource]. Acad Med.Vol. 81(3), pp. 207-
212. Mode of access: http://www.ncbi.nlm.nih.gov/ pubmed/16501260. Title from the screen.

9. Stanford Medicine [Electronic resource]. Mode of access: http://med.stanford.edu/. Title from the screen

Стаття надійшла до редакції 26.02.2018

УДК 37.035.6:371(477.8) “ҮІІІ / XIX”

DOI:

Марія Багрій, кандидат філологічних наук, докторант ДВНЗ “Прикарпатський національний університет імені Василя Стефаника"

\section{СТАНОВЛЕННЯ НАЦІОНАЛЬНОЇ ІДЕНТИЧНОСТІ ТА ВИХОВАННЯ НАЦІОНАЛЬНО-СВІДОМОЇ ОСОБИСТОСТІ У ЗАХІДНІЙ УКРАЇНІ КІНЦЯ XVIII СТ. - 1939 Р.}

Стаття присвячена становленню начіональної ідентичності та вихованню начіонально-свідомоі особистості у Західній Украӥні кінця XVIII cm. - 1939 р. Здійснено порівняння концепту національної ідентичності в окремих регіонах, описано запропоновані шляхи відновлення національного коду, досліджено принциии виховання національно-свідомої особистості крізь призму етнічного та загальногромадянського змісту. Проаналізовано символічну складову та систему архетипів начіонального становлення Західної України означеної доби. Проаналізовано терміни “національна ідентичність” $i$ “національна ідея”, потрактовано національний компонент свідомості украйнців Західної України кіния XVIII cm. -1939 p.

Ключові слова: Київська Русь; начіональна ідентичність; начіональна ідея; начіонально-свідома особистість; Західна Україна; козаитво; опришківство.

תim. 15.

Mariya Bahriy, Ph.D.(Philology), Doctoral Student State Pedagogical University "Vasyl Stefanyk Precarpathian National University"

\section{DEVELOPMENT OFNATIONALIDENTITYANDEDUCATIONOFTHE NATIONAL- CONSCIOUS PERSONALITYIN WESTERNUKRAINE INTHE ENDOFTHE YEAR XVIII- 1939}

The article is devoted to the formation of national identity and the education of the national conscious personality in Western Ukraine at the end of the thirteenth century XVIII - 1939. The comparison of the concept "national identity" in certain regions is carried out, the proposed ways of restoration of the national code are described, and the principles of education of the national conscious person are explored through the prism of ethnic and general civic content. The symbolic component and a system of archetypes of the national formation of Western Ukraine of certain age have been analyzed. The terms "national identity" and "national idea" are analyzed, the national component of Ukrainian consciousness of Western Ukraine at the end of the thirteenth century is studied XVIII - 1939.

The period of each decay of nation is transformed into a national revival, which becomes possible because the nation did not manage to destroy it. The process of another uplift begins, in which the national consciousness at the ideological level has an exceptional significance. The national idea born on the wake of the national revival forms the national self-consciousness that can be considered both an indicator and a generator of the formation and development of a new nation, its transformation, a national idea that consolidates the nation, forming the core around which a national culture is created. Only that can be considered the national idea, national identity and national self-culture as the main components of the structure of the nation, as well as indicators of its birth and revival. It is necessary to begin to overcome the complex problems of education of youth, its national-patriotic education in its own, Ukrainian tradition, on its own samples of public, scientific victory in the name of the Ukrainian state.

The national idea should be based on a deep understanding of each Ukrainian about the Ukrainian national identity, identification with it, on forming perceptions about the typical features of the Ukrainian national community, its ethnic territory, language, historical and spiritual values.

Keywords: Kievan Rus; national identity; a national idea; the national conscious personality; Western Ukraine; Cossacks; Opryshchivstvo.

$\Pi$ остановка проблеми. Терміни “національна ідентичність" і “національна ідея” були на часі тоді, коли не існувало України як держави, але вони глибоко закорінились в історичні пласти людської свідомості. Полісемантичність терміна "нація", 
допускає досить широкі трактування їхнього національного компоненту, тому “нація” i “народ” вже традиційно є нерозділеними поняттями. Дві основні лінгвістичні традиції у застосуванні поняття "нація" склалися ще у XVIII столітті. В одній цей термін асоціювався 3 поняттями “держава", “громадянство” і означав певну територіальну політичну спільноту, в іншій увага акцентувалася на етнічних i культурних особливостях, в якій спільнота поставала як мовно-культурна.

Що ж до понять “національна ідентичність” та “національна ідея", то у цьому випадку смисли цілковито залежать від уподобань. Дослідження засвідчують, що з власною “національною ідентичністю” існують проблеми, оскільки питання ідентичності політизується, і говориться про “національну ідею”. Загроза багатозначності довкола розуміння цього поняття виникла, як тільки з'явилась свобода слова. Інколи доводиться аналізувати дискурси, щоб зрозуміти, етнічний чи загальногромадянський зміст в ці поняття вкладається, оскільки існує нечіткість у застосуванні етнічної термінології, що і $є$ метою нашої статті.

У класичній традиції питання ідентичності досліджували античні філософи - Парменід, Платон, Арістотель, Плоін, неоплатоники. Проблема ідентичності розроблялась також Е. Еріксоном, Дж. Марсія, А.Ватерманом та іншими ученими. Питання націй та національної ідеї досліджували вітчизняні науковці: О. Категоренко, В. Климончук, А. Колодій, О. Куценко, І. Лубківський, В. Лісовий Н. Матвієнко, М. Михальченко, О. Рудакевич, Ю. Руденко, С. Рябов, М. Попов, Ю. Шайгородський та ін. "Національна ідея” розглядається як складний соціокультурний процес, феномен, який служить для об'єднання нації, найбільш ефективної реалізації завдань розбудови національної держави, національно-культурної духовності українського народу. Національна ідея має грунтуватися на глибокому усвідомленні кожного українця щодо української національної ідентичності, ідентифікації з нею, на формуванні уявлень про типові риси української національної спільноти, їі етнічної території, мови, історичні та духовні цінності. Як правило, у визначеннях “нації” переважає етнічний компонент, на зразок: “Термін “український народ” тотожний терміну “українська нація” й визначає етнонаціональну спільноту, яка ідентифікує себе як власний самобутній етнокультурний і етнополітичний організм на власній споконвічній етнічній території' [7, 634].

Виклад основного матеріалу. В Україні формування нації відбувалося в умовах багатовікової бездержавності, ускладненої роз'єднаністю території. Прискоренням цього процесу могла бути культурна мобілізація, проте зовсім невелика частина населення ідентифікувала себе з українською нацією. Оскільки етнічні українці самі перебували у стадії набуття національної свідомості, процес очолили бюрократичні еліти, для яких формування громадянської нації був справою їх власної легітимності та самозбереження [8, 142]. Подальші катаклізми “ громадянська війна, тривалий період панування тоталітарної диктатури, не сприяли формуванню національної ідентичності на основі співгромадянства, і водночас утримували поняття національної ідеї у вузьких рамках етнічності.

Основи української національної ідентичності можна відшукати в глибинах історії, де Київська Русь наочно демонструвала уявлення про “рід руський” та "руську землю” $[11,196]$. Тривала бездержавність зумовлювала численні кризи ідентичності, спровоковані спочатку опольщенням, а потім зросійщенням українських елітних прошарків. Та й сама ідентичність була радше становою, релігійною, регіональною, ніж національною. Лише у XVIII столітті усвідомлення елітою своєї нерозривної єдності з етнічною територією, згуртування навколо власних політико-правових цінностей i інституцій, створення власного історичного міфу, істотно розширили ідентифікаційний простір. Вихід за межі етнорелігійної ідентифікації дає підстави зробити висновок: протягом XVIII століття в середовищі соціальної еліти УкраїниГетьманщини розпочався процес формування проявів національної ідентичності, характерний для сучасної модерної нації [13, 16]. На побутовому рівні українська ідея, національна ідентичність існувала як уособлення народного духу, прагнення до свободи самовиявлення. Вказуючи на основні історичні джерела щодо формування українського етносу, В. Жмир за початок аналізу процесу націєтворення бере XIV ст., період, коли українські землі опинилися у сфері політико-економічного впливу Великого князівства Литовського і Речі Посполитої $[5,84]$. Інший український дослідник О. Струкевич, простежуючи витоки “української нації до націоналізму”, звертає увагу на те, що лише в XVII і на початку XVIII ст. - у добу козацтва виразно виявилися ознаки саме національної, а не етнічної ідентичності $[13,19]$. Особливістю національного самовизначення українців було гуртування навколо певної соціальної групи козацтва. Козацтво не випадково з'являється на 


\section{СТАНОВЛЕННЯ НАЦІОНАЛЬНОЇ ІДЕНТИЧНОСТІ ТА ВИХОВАННЯ НАЦІОНАЛЬНО-СВІДОМОӤ ОСОБИСТОСТІ У ЗАХІДНІЙ УКРӒ̈НІ КІНЦЯ ХVIII СТ. - 1939 Р.}

землях Київської Русі, воно стало продовженням iii державницьких традицій і значною мірою декларувалися козацькою елітою. Саме волелюбний дух козаччини став головним чинником формування національного ідеалу українця, сформував своєрідний код нації, зберіг рушійну силу українства. Тому момент формування української нації відбувався уті часи, коли вирувала національно-визвольна боротьба українців за свою незалежність, а козацький дух українства витав у етнічній історії українців після того, як була скасована Запорозька Січ і козацтво України, і навіть посилився як своєрідна реакція на опір. Саме від козацтва починаються витоки української нації, оскільки з ним пов'язане пробудження національної самосвідомості, формування національних інтересів і національної мети, тобто всіх необхідних для нації компонентів. Запорозька Січ є тим головним механізмом, котрий консолідує етнос, створює передумови для відродження нових націй на грунті попередніх. Він формує національні інтереси, а вони є основою нації, підгрунтям для регулювання певних сфер суспільних відносин без зміни їх змісту процесів. Рушійною силою цих процесів виступає національна ідея, що випливає 3 національних інтересів і яка формує національну культуру, а через неї і національну самосвідомість.

Ситуація щодо національного самоусвідомлення ускладнювалася й тим, що українські етнічні землі протягом тривалого часу входили до складу декількох державних утворень: Польщі, Угорщини, Румунії, Османської, АвстроУгорської, Російської імперій, а згодом і СРСР. Ці держави чинили соціальний, адміністративний та ідеологічний тиск на українське населення, щоб ліквідувати його відмінності від панівної нації. Українська еліта віками втрачала первісну культуру та самосвідомість. У другій половині XVII століття після поділів Польщі, українські землі опинилися у складі двох імперій Російської та Австро-Угорської. Хоча ідея єдиної України продовжувала жити в історичній пам’яті та політичній думці народу, реалізувати їі можна було лише в контексті протиборства цих державних утворень, при тому, що соціальна мобільність української нації лишалася невисокою, а асиміляційний тиск $з$ різних сторін невпинно зростав через геополітичні амбіції і воєнні авантюри. Росія мріяла про приєднання Галичини, Австро-Угорщина плекала плани захоплення всіх західноукраїнських земель.

Незважаючи на русифікацію й полонізацію, українська еліта усвідомлювала, що вона є іншою, і зберігала етнічну самобутність і тісний зв'язок, i в Речі Посполитій, і в Російській імперії. Однією 3 основних причин втрати українцями державності М. Міхновський вважав відсутність внугрішньої єдності й висував ідею національного солідаризму, яка має об'єднати окремі частини нації в єдине ціле: “Одна, єдина, нероздільна, вільна, самостійна Україна від гір Карпатських аж по Кавказькі... Усі нещастя, що до цього часу терпить український нарід, від того, що він до останніх часів не поглядав на свою справу національно, а соціально він не мав ідеалу самостійної України. Український нарід того часу не хотів національної незалежності, а соціальних полегшень" [10, 147 - 148].

Ідея пізнього українського націоналізму про те, що кожен народ повинен говорити своєю мовою, ще не набула визнання. Створення у Львові в 1868 р. товариства "Просвіта" стало визначним явищем для відродження української національної культури та проблеми самовизначення. В основу свого мислення і в програму своєї діяльності народовці ставили освітню й організаційну працю в народних масах. Вони розмовляли чистою народною мовою й намагалися впроваджувати іï в літературний ужиток і громадське життя, пресу i театр, школу й науку. Однак власне українських осередків освіти на Західній Україні було вкрай мало, у більшості міських шкіл викладання велося німецькою мовою, у Львівському університеті німецькою й латинською. У народних школах переважала польська (у Східній Галичині), румунська (у Північній Буковині) або угорська (на Закарпатті) мова. На цьому тлі вирізнявся Руський інститут - тимчасовий допоміжний навчальний заклад при Львівському університеті для студентів-українців філософського, юридичного й теологічного факультетів, у якому викладання велося українською книжною мовою. Для слухачів інституту Петро Лодій, професор філософії Львівського університету в 1787-1802 pр., переклав $з$ латинської на українську книжну мову й опублікував підручник німецького філософа Х. Баумейстера "Наставления любомудрия нравоучительного” (1790), вживши в перекладі народні вислови. Він же у своїх лекціях пропагував ідеї необхідності розбудови наукової картини світу, впорядкування суспільного життя на засадах розуму шляхом наукових досліджень, пошуку власної ідентичності. Завдяки П. Лодію, математику, фізику, природознавцю-просвітителю I. Земанчику, мовознавцеві I. Лаврівському, а також іншим викладачам, Руський інститут за час свого існування (1787 - 1806) підготував чимало освічених випускників із місцевого населення, зокрема знавців української книжної мови. 

ОСОБИСТОСТІ У ЗАХІДНІЙ УКРӒ̈НІ КІНЦЯ ХVIII СТ. - 1939 Р.

Жорстка політика денаціоналізації здійснювалася й на тій частині Західної України, де панувала Польща - постанова сейму 1817 р. про викладання в школах Західної України лише польською мовою, розпорядження польського сейму 1789 р. про закриття українських церковних шкіл, закон 1924 р., про обмеження вживання української мови в адміністративних органах, судах та школах. Від 1920 р. окуповану Західну Україну в Польщі офіційно почали називати “Малопольська Всходня”, а українців “русинами”.

Варто зауважити, що проблема полонізації була дуже актуальною для Галичини. Завдяки сприятливим умовам соціального й національного розвитку українці Галичини спромоглися пройти в XIX ст. типовий для більшості бездержавних народів шлях націєтворення і стати цілком модерною європейською нацією - 3 чіткою національною самосвідомістю й повноцінним громадянським суспільством. Хоча соціальні й культурні умови підштовхували українську еліту до полонізації, сама ця еліта кількісно була занадто мала, а шанси полонізувати українське селянство були незначні. Соціальні умови в Галичині були такі, що українець міг бути лише ремісником чи селянином, але і не всі поляки були дворянами i землевласниками, проте майже всі шляхтичі й землевласники були поляками. Тому полонізація української еліти загалом незначно впливала на загальний стан української культури в Галичині. Галицьке українське селянство чинило жорсткий опір польським землевласникам. На цих землях завжди був великий резерв для розвитку антипольської української ідентичності, яка почала виразно формуватися наприкінці XIX ст. Уніатська церква також чинила серйозний опір полонізації $[15,36]$. Відносно вільна Галичина забезпечила модель політичної мобілізації, використану українськими політиками після революції 1905 р. На 1900 р. галичани мали вже конкретну політичну програму, яку остаточно сформулював Ю. Бачинський у гаслі “Україна, Незалежність, Сдність” [1, 420]. Це гасло стосувалося не лише галицької автономії, а й усієї України. Ідентичність, яка пропонувалася у Галичині, мала бути чіткою і конкретною, i це зумовило розвиток на межі XIX - XX ст. сильного почуття місцевого націоналізму, який вирізнявся своєю ідентичністю проти поляків [15, 36-37]. Небажання польської еліти визнати національні прагнення і права етнічних меншин Галичини було особливо помітне, результатом чого став розвиток української національної ідеології 3 вираженим правим ухилом, який був стимульований гірким досвідом Першої світової війни, революцією 1917 р. та деструкцією двох незалежних українських держав. Цей напрямок відображений у так званій державницькій школі української історіографії, основною вимогою якої було створення незалежної української держави і заперечення ідеї соціалізму, яка підтримувалася інтелектуалами на поч. ХХ ст. Цією школою було адаптовано й розвинуто ідею вузького націоналізму [6, 12 - 23]. Починаючи з 1920 р., лідери української інтелектуальної еліти проголошують націоналізм і праву ідеологію. Українська національна ідентичність у Галичині цього часу відображала складний стан протистояння двом ворожим націоналістичним ідеологіям: польській і російській. Головним ідеологом цієї ідентичності став Д. Донцов [4, 118].

Павло-Роберт Магочій вважав каталізатором ідеї української національної єдності в Галичині не давню політичну традицію, а прийшлу з-за меж України ідеологію націоналізму. Розглядаючи аналітичну структуру національного руху в XIX ст., вчений писав про взаємодію двох природних його структур - “ієрархії численних лояльностей” та “взаємовиключних свідомостей”, тобто усвідомлення неможливості водночас ідентифікувати себе, для прикладу, і малоросом (українцем), і росіянином. Так, серед діячів "Руської трійці” представником “взаємовиключних свідомостей” був М. Шашкевич, який помер у молодому віці й залишився “ідеологічно чистим" в очах українських патріотів, тоді як І. Вагилевич представляв польсько-українську, а Я. Головацький - російсько-українську лояльність [9, 156 - 158]. Історична пам'ять українців, в якій міцно закарбувалася ідея “однієї великої України”, допомогла радянським урядовцям надати видимість відповідності цінностям і нормам традиційної політичної культури Західної України наприкінці 30-х pp. ХX ст. Під впливом тоталітарного ідеологічного тиску і притаманної радянському режиму системи економічних, політичних і культурних відносин відбулися суттєві зміни у національній ментальності. Ї̈ї основні риси дещо притуплювалися і на них накладалися притаманні вже радянські ментальності: “пасивність особи - відсутність волі до поліпшення життя власними силами, що доповнюється формальною активністю, про людське око, і напоказ, головне - створити враження, що людина працює, а не працювати на певний результат; комплекс меншовартості - i відчуття власної неспроможності через некомпетентність і непрофесіоналізм, зворотним боком чого $є$ невмотивована амбіційність і 


\section{СТАНОВЛЕННЯ НАЦІОНАЛЬНОЇ ІДЕНТИЧНОСТІ ТА ВИХОВАННЯ НАЦІОНАЛЬНО-СВІДОМОӤ ОСОБИСТОСТІ У ЗАХІДНІЙ УКРАЇНІ КІНЦЯ ХVІІІ СТ. - 1939 Р.}

хамство; патерналізм - і очікування від влади розв'язання власних проблем; безпорадність, сподівання на розв'язання проблем ззовні, на чиюсь гуманітарну допомогу" $[12,243]$. Проте домінування в політичному житті, репресії нової влади, де не знайшлося місця для українських національних почуттів, вчинили так, що значна частина населення Західної України опинилася під час Другої світової війни в антирадянському таборі, захищаючи зі зброєю в руках своє уявлення про права нації. Ця боротьба набуває особливої гостроти й значимості, якщо його спроектувати на український етнос, який як відомо, формувався в умовах роз'єднаності і, власне, відсутності держави. Українці здобули державність лише в 1918 році, а об'єдналися ще пізніше - у 1939 році.

Найважливішим чинником було те, що західні українці, незважаючи на багатовікове національне поневолення польською, австрійською, угорською та молдавською державами, зберегли свою мову, віру, звичаї. Наприкінці XVIII ст. західноукраїнські землі опинилися під владою єдиної держави Австрійської монархії: Східна Галичина - 1772 р., Північна Буковина - 31774 р. Закарпатська Україна, а за тодішньою історичною назвою, Підкарпатська Русь, перебувала у складі Австрії ще 3 кінця XVII ст. Формування національної самосвідомості західних українців ускладнювалося тим, що вони являли собою тільки частину українського народу, більшість якого перебувала під владою іншої держави - Росії.

Посилення національного та кріпосницького гніту на західноукраїнських землях привело до виникнення руху опришків, який спочатку охопив Прикарпаття, а згодом поширився на Закарпаття й Буковину. У Карпатські гори втікали покривджені селяни та бідні міщани, які формували невеликі загони, які нападали на панські маєтки, замки, на орендарів і лихварів, а захоплене майно роздавали сільській бідноті. В очах простого народу це були народні месники легендарні й непереможні герої [2, 68]. Найвищого піднесення опришківський рух досяг у 1738 - 1759 рр. Легендарним ватажком опришків $30-40$-х років XVIII ст. став Олекса Довбуш [3, 24]. У першій половині XIX ст. в Галичині, на Закарпатті та Буковині діяло понад 50 загонів повстанців, ватажками яких були В. Яким'юк, Д. Марусяк, М. Шталюк, В. Фреюк, І. Вередюк, М. Циган, I. Волощук та ін. Останнім ватажком опришків був М. Драгирук (Бордюк), прилюдно страчений 1878 року в Коломиї $[14,58]$. Селянські бунти й повстання відбулися у Волі Якубовій, (1819), інших селах Самбірщини (1823), на Сколівщині
(1824 - 1826), Чортківщині (1838), у Нагуєвичах (1832), Демні (1842). У 1843 - 1844 рр. у Північній Буковині виник антифеодальний селянський рух під проводом Лук'яна Кобилиці, 1846 р. спалахнуло селянське повстання у Східній Галичині.

Висновки. Період кожного занепаду нації перетворюється в національне відродження, яке стає можливим тому, що націю не встигли знищити. Починається процес чергового піднесення вгору, в якому виняткове значення має національна свідомість на ідеологічному рівні. Національна ідея, що зароджується на хвилі національного відродження, формує національну самосвідомість, що можна вважати і показником, і генератором становлення і розвитку нової нації, iї трансформації, національну ідею, що консолідує націю, утворюючи стрижень, довкола якого твориться національна культура. Тільки так можна вважати національну ідею, національну самосвідомість та національну самокультуру головними складниками структури нації, як і показниками іiі народження та відродження. Розпочинати долання надскладних проблем треба

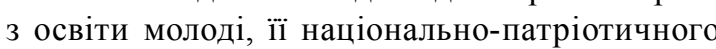
виховання на власній, українській традиції, на власних зразках громадської, наукової звитяги в ім'я Української держави.

\section{ЛІТЕРАТУРА}

1. Бачинський Ю. Економічні підстави самостійності націй // Націоналізм: Антологія. 2ге вид. / Упоряд. О. Проценко, В. Лісовий. - К.: Смолоскип, 2006. - С. $414-424$.

2. Грабовецький В. Анифеодальна боротьба карпатського опришківства XVI-XIX ст. / В. Грабовецький. - Львів, 1966. - 328 с.

3. Грабовецький В. Олекса Довбуш (1700$1745)$ / В. Грабовецький. - Львів, 1994. - 289 с.

4. Донцов Д. Дух нашої давнини / Д. Донцов. - Дрогобич: Відродження, 1991. - 341 с.

5. Жмир В. Ф. На шляху до себе (Етносоціологічна розвідка) / В. Ф. Жмир. - К.: Демократичні ініціативи, 1995. - 112 с.

6. Заєць О. Націоналізм і національна демократія: витоки конфлікту(1920-1930) / О. Заєць // Сучасність. - 1994. - № 2. - С. 12 - 23.

7. Іванченко I. Український народ. Мала енциклопедія етнодержавознавства / І. Іванченко. - К., 1996. - С. 634.

8. Касьянов Г. Украина 1991-2007. Очерки новейшей истории / Г. Касьянов. - К.: Наш час, 2008. - C.131-152.

9. Магочій П.-Р. Галичина. Історичні есе / Павло Роберт Магочій. - Львів, 1994. - 322 с. 
10. Міхновський М. Справа української інтелігенції в програмі Української Народної партії (Фрагменти) // Політологія. Кінець XIX - перша половина XX ст.: Хрестоматія/ За ред. О. І. Семківа. - Львів: Світ, 1999. - С. 142 - 154.

11. Нагорна Л. Політична культура українського народу: історична ретроспектива і сучасні реалії / Л. Нагорна. - К.: Стилос, 1998. - 278 с.

12. Політологічний енциклопедичний словник. - К.: Генеза, 2004. - С.335.

13. Струкевич О. К. Українська “нація до націоналізму”: пошуки, критерії ідентичності в Україні-Гетьманщині XVII ст. // Український історичний журнал. - 1999. - № 6. - С. 18-21.

14. Целевич Ю. Опришки // Розвідки про народні рухи на Україні-Русив XVIIIвіці/Ю.Целевич. - Львів, 1897. - 321 с.

15. Черкес Б. С. Національна ідентичність в архітектурі міста: Монографія / Б. С. Черкес. Львів: Вид-во Національного університету “Львіська політехніка”, 2008. - 268 с.

\section{REFERENCES}

1. Bachinsky, Yu. (2006). Ekonomichni pidstawu samostiynosti naziyi [Economic basis of the independence of nations]. Nationalism: Anthology. 2nd form. (Ed.). O. Protsenko, V. Forest. Kyiv: Smoloskyp, pp. 414-424. [in Ukrainian].

2. Grabovetsky, V. (1996). Aantufeodalna borotba karpatskoho opruchkivstva XVI-XIX st. [Anifeudal struggle of the Carpathian Opryshism of the XVIXIX centuries]. Lviv. [in Ukrainian].

3. Grabovetsky, V. (1994). Oleksa Dovbusch (1700-1745) [Oleksa Dovbush (1700-1745)]. Lviv. [in Ukrainian].

4. Dontsov, D. (1991). Duch naschoi dawnunu [The Spirit of Our Antiquity]. Drogobych, "Vidpozhenie", 341 p. [in Ukrainian].

5. Zhir, VF. (1995). Na schlyachu do sebe [On the Way to Himself(Ethno-Sociological Intelligence)]. Kyiv: Democratic Initiatives, 112 p. [in Ukrainian].

6. Hare, O. (1994). Nazionalizm i nazionalna demokratiya-wutoku konfliktu [Nationalism and national democracy: the origins of the conflict (19201930)]. Contemporary, no. 2, pp. $12-23$. [in Ukrainian].

7. Ivanchenko, I. (1996). Ukrainskuy narod [Ukrainian people]. Small Encyclopedia of ethno-state studies. Kyiv, p. 634. [in Ukrainian].

8. Kasyanov, G. (2008). Ukraina 1991-2007. Ocherki noweyschey istorii [Ukraine 1991-2007. Essays on the latest history]. Kyiv: Our time, pp.131152. [in Rusian].

9. Magochiy, P.-R. (1994). Haluchuna. Istoruchni ese [Galicia Historical essays]. Lviv, 322 p. [in Ukrainian].

10. Mikhnovsky, M. (1999). Sprawa ukrainskoi intelihenziyi w prohrami Ukrainskoi Nazionalnoi Partiyi [The Case of the Ukrainian Intelligentsia in the Program of the Ukrainian People's Party (Fragments)]. Political Science. The end of the nineteenth and first half of the twentieth century: Hestomatiya. (Ed.). O.I. Semkiv. Lviv: World, pp. 142 - 154. [in Ukrainian].

11. Nagorna, L. (1998). Polituchna kultura ukrayinskoho narodu: istoruchna retrospektuwa $i$ suchasni realiyi [Political culture of the Ukrainian people: historical retrospective and modern realities]. Kyiv: Stilos, 278 p. [in Ukrainian].

12. Politolohichnuy Enzeklopeduchnuy Slownuk (2004). [Politology Encyclopedic Dictionary]. Kyiv: Genesis, p. 335. [in Ukrainian].

13. Strukevich, O.K. (1999). Ukrainska "naziya do nazionalizmu" [Ukrainian "nation to nationalism": searches, criteria of identity in Ukraine-Hetmanate of the XVII century]. Ukrainian Historical Journal. No. 6, p. 18. [in Ukrainian].

14. Tselievich, Y. (1897). Opruschku [Opryshka. In the book: Intelligence about popular movements in Ukraine-Rus in the XVIII century]. Lviv. [in Ukrainian].

15. Cherkes, B. S. (2008). Nazionalna identuchnist $w$ architekturi mista [National identity in the city's architecture: Monograph]. Lviv: View of the National University of Lviv Polytechnic, 268 p. [in Ukrainian].

Стаття надійшла до редакції 06.03.2018

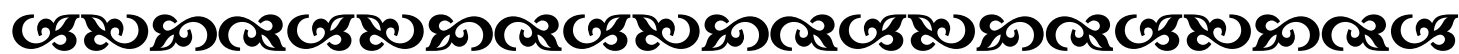

"Мета християнського виховання не змінюється залежно від політичних або білософських віянь, а трунтується на Божественному одқровенні. Минають століття, змінюються суспільні умови, а природа людсьқої душі залишається незмінною".

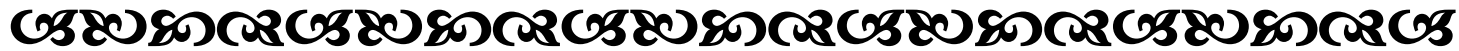

